\title{
Arti Penting Sense of Crisis bagi Humas dan Pimpinan Perguruan Tinggi
}

\author{
Narayana Mahendra Prastya \\ Program Studi Ilmu Komunikasi, Fakultas Psikologi dan Sosial Budaya, \\ Universitas Islam Indonesia (UII) Yogyakarta \\ Email: narayana@uii.ac.id
}

\begin{abstract}
Abstrak
Tulisan ini bertujuan untuk memberikan rekomendasi tentang keterlibatan dan kerjasama antara humas dan pimpinan perguruan tinggi dalam menghadapi situasi krisis. Hal ini disebabkan karena organisasi perguruan tinggi juga berpotensi untuk terkena krisis. Krisis merupakan situasi yang menarik atensi media untuk meliput. Itu sebabnya dalam situasi krisis organisasi harus mampu melayani media dengan baik, dalam konteks memberikan informasi dan akses liputan. Di sisi lain, kegiatan hubungan media yang dilakukan oleh perguruan tinggi didominasi tujuan untuk membentuk citra positif. Itu sebabnya dalam situasi krisis, perguruan tinggi terlihat mengalami sejumlah kendala ketika harus menghadapi media. Manajemen krisis merupakan tugas utama bagi unit kerja humas. Namun agar kinerja humas menjadi maksimal, maka perlu adanya dukungan dari pimpinan perguruan tinggi. Bahkan pada situasi-situasi tertentu, pimpinan perguran tinggi harus tampil dan memberikan penjelasan kepada media.
\end{abstract}

Kata kunci: hubungan media, humas perguruan tinggi, manajemen krisis

\begin{abstract}
No organization is invulnerable towards crisis, including university and/or educational organization. This article aims to give a recommendation about the involvement and collaboration between the Public Relations practitioner and the top management in university and/or educational organization, in order to face the crisis situation. Crisis situation usually attracts the media to cover it. It means an organization should serve the media well, in term giving the information and access to get information. In the other side, media relations activities that usually do by the universities is dominated by making good organization image. Therefore, a university's public relations seems to find difficulties when must face the media in a crisis situation. Crisis management is the main duty of a public relations practitioner. But, he needs support from the top management. In a particular situation, representatives from the top management should appear in the media.
\end{abstract}

Keyword : crisis manamgement, higher education organization, media relations, public relations, 


\section{LATAR BELAKANG}

Titik berangkat dari tulisan ini adalah pernyataan sejumlah ahli seperti Lawrence Barton, Marion K Pinsdorf, dan Jack A.Gottschalk yang menyatakan krisis dapat menimpa semua jenis organisasi. Mulai dari korporasi atau perusahaan, organisasi nir-laba, badan pemerintah, lembaga-lembaga keagamaan, kerjasama, hingga keluarga; bentuk krisis bisa kebangkrutan yang mengalami sebuah outlet rumah makan waralaba, hingga penghentian operasional sebuah indiustr (Ngurah Putra, 1999 : 86).

Itu berarti, organisasi perguruan tinggi pun tidak kebal dari krisis. Sejumlah kejadian yang dapat memicu krisis di perguruan tinggi, misalkan pelanggaran etika akademik, penuruan performa lembaga pendidikan sehingga beberapa di antaranya terancam tutup, implikasi regulasi dan/atau sosial politik terhadap lembaga perguruan tinggi, perilaku negatif dari staf pendidik (dosen)/peserta didik/karyawan dari perguruan tinggi tersebut yang sampai berujung pada urusan dengan kepolisian atau hukum (Gainey, 2010: 305; Sati, 2017: 129).

Di Indonesia, sejumlah krisis pernah menghinggapi perguruan tinggi. Misalkan kejadian peserta didik meninggal dunia secara tidak wajar ketika tengah mengikuti kegiatan ekstrakurikuler, plagiasi yang dilakukan oleh sejumlah staf pengajar, praktek jual beli ijazah, penggunaan ijazah palsu oleh sejumlah tenaga pengajar, konflik internal yang mengganggu roda organsiasi perguruan tinggi dan hak-hak mahasiswa, performa perguruan tinggi yang menurun sehingga terancam tutup, dan sebagainya.

Peristiwa-peristiwa seperti yang telah disebutkan dapat menjadikan perguruan tinggi berada dalam situasi krisis yang ditandai dengan ciri-ciri yakni: menjadi sorotan masyarakat dan cenderung negatif dan menuntut organisasi yang tengah ditimpa krisis tersebut untuk berkomunikasi dengan pemangku kepentingan secara sigap, cepat, dan dengan konten informasi yang akurat (Hariyanti, 2009: 192).

Situasi ini menuntut kesiapan perguruan tinggi menghadapi krisis. Faktanya, lembaga pendidikan terlihat keteteran saat menghadapi krisis atau dalam menangkal isu negatif. Penanganan isu negatif bersifat responsive tanpa standar operasional baku (Ariani, 2016), hingga ada yang memilih menutup diri dan jaga jarak dengan media (Setyanto dan Anggarina, 2015) Kondisi ini menunjukkan bahwa perguruan tinggi tidak siap dalam menghadapi krisis.

Padahal, organisasi idealnya memiliki manajemen yang mengelola dan menanggulangi krisis. Kegagalan dalam manajemen krisis akan membuat organsiasi ada di posisi yang semakin sulit, karena dianggap tidak mampu menangani masalah atau bahkan dituding tidak bertanggungjawab untuk menyelesaikan persoalan (Hariyanti, 2009: 199).

Lantas, siapa pihak di perguruan tinggi yang perlu memiliki kesiapan menghadapi krisis? Ada dua pihak, yakni humas perguruan tinggi dan pimpinan perguruan tinggi. Humas merupakan ujung tombak dalam manajemen krisis (Ngurah Putra, 1999: 83). Sedangkan keterlibatan pimpinan organisasi dalam manajemen krisis sangatlah menentukan (Ulmer, et.al. 2011) dan mempengaruhi bagaimana kinerja dari humas di perguruan tinggi (Sati, 2017; Setyanto dan Anggarina, 2015). 
Tulisan ini mengambil contoh kasus tentang manajemen krisis oleh Universitas Islam Indonesia (UII) Yogyakarta dalam peristiwa meninggalnya tiga orang mahasiswa dalam kegiatan Pendidikan Dasar Mahasiswa Pecinta Alam UII (Diksar Mapala UII) di bulan Januari 2017.

Sebagai acuan dalam hal penelitian terdahulu, terdapat dua naskah akademik yang fokus mengenai penangan krisis di perguruan tinggi di Indonesia. Ariani (2016) membahas manajemen isu oleh humas Universitas Gadjah Mada (UGM) Yogyakarta, ketika perguruan tinggi trsebut dilanda demonstrasi yang diikuti oleh sebaian besar mahasiswa dan karyawan pada Mei 2016. Hasil penelitian menunjukkan humas UGM telah melakukan kegiatan manajemen isu, namun tidak terstruktur karena tidak memiliki standar operasional prosedur. Ada pun sumber data dari penelitian Ariani adalah wawancara dengan pihak humas UGM.

Selanjutnya adalah Sa'diyah (2017) yang membahas mengenai konten pemberitaan media massa mengenai kasus Diksar Mapala UII dan pernyataan resmi UII yang disampaikan melalui situsweb resmi perguruan tinggi: www.uii.ac.id, dengan menggunakan analisis isi kualitatif . Hasil analisis menunjukkan empat tema yang dominan yakni : upaya UII membentuk tim investigasi dan crisis centre; informasi mengenai bentuk kepedulian/simpai UII kepada korban; penggantian manajemen organisasi; dan memberikan sanksi berat kepada pelaku. Temuan menarik lain dari penelitian ini adalah perubahan desain dan konten situsweb resmi UII pasca tertangkapnya pelaku yang menewaskan mahasiswa peserta Diksar Mapala UII. Desain situsweb resmi menjadi lebih menarik, dan informasi seputar kasus Diksar Mapala UII telah dihapus dari menu informasi di www.uii.ac.id.

Perbedaan tulisan ini dengan dua tulisan terdahulu adalah terletak pada data yang digunakan yakni dengan melakukan wawancara terhadap wartawan yang meliput tragedy Diksar Mapala UII 2017. Artinya, tulisan ini fokus pada bagaimana respon media terhadap aktivitas hubungan media yang dilakukan oleh UII.

Batasan dari tulisan ini adalah aktivitas hubungan media UII dalam situasi krisis tersebut. Tema hubungan media dipilih karena hal tersebut merupakan aktivitas yang umum dilakukan oleh perguruan tinggi (dalam situasi normal atau tidak ada krisis), dan hubungan media merupakan salah satu kegiatan yang penting dilakukan oleh satu organisasi dalam situasi krisis. Dalam situasi krisis, media memiliki pengaruh media yang besar terutama dalam mempengaruhi pandangan masyarakat terhadap organsiasi. Bahkan, kondisi ini dapat membuat masyarakat jadi lebih percaya informasi media dan wartawan disbanding dengan humas organisasi itu sendiri (Farihanto, 2014; Nurjanah, dkk. 2015; Puspitasari, 2016).

Data tulisan ini menggunakan wawancara dengan perwakilan dari redaksi media di Yogyakarta, untuk mengetahui bagaimana pendapat mereka tentang penyediaan informasi dari UII selama kasus tersebut.

Faktanya, wartawan masih belum puas dengan aktivitas hubungan media perguruan tinggi saat situasi krisis. Problem yang muncul adalah wartawan merasa dihalangi saat liputan di perguruan tinggi yang tengah terkena krisis, sikap tertutup perguruan tinggi, dan hal ini 
dipandang oleh wartawan dapat mempengaruhi hubungan baik antarinstitusi (perguruan tinggi dengan media) yang telah dibangun sebelumnya (Nurjanah, dkk. 2015; Setyanto dan Anggarina, 2015).

Keberhasilan aktivitas hubungan media dalam situasi krisis bergantung pada kualitas dari informasi seperti materi press release; pemantauan trend berita untuk menjadi dasar bagi organisasi untuk menyusun pernyataan resmi; relasi personal yang baik antara pihak humas organisasi dan wartawan; dan relasi yang baik antarlembaga, antara organisasi dengan institusi media (Fil Haq, 2011; Miela Putra, 2012; Zoch dan Molleda, 2006)

Batasan hubungan media dalam tulisan ini adalah penyediaan informasi (information subsidies). Ada tiga hal berkaitan dengan penyediaan informasi. Pertama organisasi perlu menyediakan narasumber yang sesuai dengan kebutuhan wartawan. Itu berarti organisasi harus proaktif dalam menyediakan informasi dan menempatakan juru bicara yang memang memahami konteks situasi krisis dan sesuai dengan kebutuhan wartawan Pada umumnya wartawan menjadikan pimpinan tertinggi organisasi merupakan narasumber yang menjadi prioritas utama (Zoch dan Molleda, 2006: 284, 294).

Dalam situasi krisis, kehadiran seorang pimpinan organisasi merupakan hal yang penting. Ulmer, et.al (2011: 6569) menyatakan bahwa pimpinan organisasi harus terlibat dalam komunikasi krisis, merespon pertanyaan wartawan, berkomunikasi dengan korban krisis, dan harus terlihat hadir di depan publik (melalui media) guna membentuk kesan kepada publik bahwa organisasi memang bersungguh-sungguh dalam menangani krisis. Ketika pimpinan organisasi terkesan bersembunyi, lamabt merespon, atau memberikan materi informasi yang bertentangan dengan ekspektasi masyarakat, maka di situ organisasi mengahdapi risiko besar.

Dalam konteks perguruan tinggi, pimpinan perguruan tinggi merupakan narasumber yang diharapkan oleh wartawan, karena memiliki derajat kepercayaan yang tinggi. Kehadrian pimpinan perguruan tinggi sebagai narasumber dapat membuat komunikasi menjadi lebih efektif, karena narasumber tersebut sesuai dengan kebutuhan wartawan (Farihanto, 2014: 59). Menurut Setyanto dan Anggarina (2015: 224) rektor merupakan salah satu narasumber kunci yang dibutuhkan wartawan dalam liputan di perguruan tinggi.

Hal kedua dari penyediaan informasi adalah memperhatikan informasi tentang isu serupa dari pihak lain. Ada pun pihak lain yang umumnya menjadi pertimbangan media untuk diwawancarai adalah public relations organisasi atau juru bicara, presiden, kelompok kepentingan, pengamat ilmiah, dan pengacara (Zoch dan Molleda, 2006: 274, 290-291). Dalam situasi krisis, organisasi harus mampu memenangi pertarungan opini di masyarakat, pasalnya penilaian masyarakat akan mempengaruhi legitimasi organisasi. Seperti dikutip dari Kriyantono (2012: 214), dalam krisis hal yang berupa persepsi dapat diyakini sebagai kebenaran.

Hal ketiga berkaitan dengan teknis liputan, organisasi harus memfasilitasi wartawan dalam proses pencarian informasi di organisasi tersebut (Zoch dan Molleda, 2006: 284, 290-291). Ada 
kecenderungan, dalam situasi krisis organisasi cenderung membatasi akses liputan media, karena khawatir apabila terekspos media, maka krisis akan menjadi semakin parah. Alhasil, media dipandang sebagai lawan yang "kejam dan intimidatif". Padahal, tindakan membatasi akses atau menutup diri itu bisa berisiko semakin menyudutkan posisi organisasi dalam keadaan krisis. Wartawan yang merasa dihalangi dalam meliput, kemudian memberitakan kendala yang mereka alami, dan hal tersebut akan menimbulkan kesan di masyarakat bahwa organsiasi tengah menyembunyikan sesuatu (Kriyantono, 2012; Pusputasari, 2016)

Akses informasi berkaitan dengan ketersediaan narasumber dan kebutuhan informasi. Berkaitan dengan narasumber, wartawan membutuhkan kemudahan dalam kontak narasumber, informasi yang cepat, dan transparan (Nurjanah, dkk. 2016: 23). Berkaitan dengan kebutuhan informasi, pertanyaan yang umumnya muncul dari media adalah : (1) penjelasan mengenai kejadian/apa yang terjadi, (2) siapa yang terlibat dan bertanggungjawab dalam terjadinya krisis, (3) apa dampak krisis bagi masyarakat, dan (4) tindakan yang dilakukan oleh organisasi dalam menghadapi krisis (Puspitasari, 2016: 117). Idealnya organisasi mampu menjawab pertanyaan tersebut. Menurut Kriyantono (2012: 246-247) pernyataan dan tindakan dari organisasi akan mempengaruhi persepsi publik terhadap organisasi dan krisis tersebut.

Paparan konseptual di atas mengenai kebutuhan media terhadap humas dan pimpinan perguruan tinggi dalma situasi krisis, menjadi menjadikan tema hubungan media sebagai titik masuk bagi proposisi "pentingnya sense of crisis bagi humas dan pimpinan perguruan tinggi”.

\section{METODE PENELITIAN}

Penelitian ini menggunakan metode deskriptif kualitatif. Tujuan peneliitan adalah membuat deskripsi secara sistematis, factual dan akurat mengenai fakta-fakta. Teknik pengumpulan data adalah melakukan wawancara dengan pihak perwakilan redaksi media massa yang melakukan liputan berkaitan dengan tragedi diksar Mapala cara tanya jawab dengan menggunakan panduan wawancara (Nurjanah,dkk.2015). Media tersebut dipilih berdasarkan keterwakilan platform media (cetak, penyiaran, online) dan jenis perusahaan media (lokal, nasional) (Lihat Tabel 1).

Peneliti mengirimkan permohonan wawancara kepada 12 media yang ada di Yogyakarta. Sepuluh media menyatakan kesediaan untuk dijadikan narasumber wawancara. Wawancara berlangsung pada periode bulan Juli hingga Oktober 2017. Hingga batas waktu penelitian ini (November 2017) ada dua media yang tidak diwawancarai. Satu media menyatakan tidak bersedia diteliti berkaitan dengan perizinan (NetTV Biro Yogyakarta) dan satu media tidak memberikan respon atas permohonan peneliti (Tribun Jogja).

Setiap sesi wawancara berlangsung antara 25 menit hingga 30 menit. Mayoritas narasumber wawancara adalah pada level manajerial, yakni penanggungjawab media (Kepala Biro) atau penanggungjawab rubrik (redaktur atau redaktur pelaksana). Hasil dari wawancara tersebut kemudian dikelompokkan dan dibahas berdasarkan 
teori/kerangka pemikiran yang berkaitan dengan aktivitas hubungan media dalam situasi krisis.

Tabel 1. Nama Media yang menjadi Narasumber

\begin{tabular}{|c|c|c|c|}
\hline No & Nama Media & Nama Narasumber & Jabatan* \\
\hline 1 & Harian Jogja & Nugroho Nurcahyo & Redaktur Pelaksana \\
\hline 2 & Kedaulatan Rakyat & $\begin{array}{l}\text { (1) Primaswolo Sujono; } \\
\text { Ardhike Indah }\end{array}$ & $\begin{array}{l}\text { (1) Redaktur } \\
\text { pelaksana; } \\
\text { Reporter }\end{array}$ \\
\hline 3 & Radar Jogja & Yogi Isti Pudjiaji & $\begin{array}{ll}\text { Wakil } & \text { Pemimpin } \\
\text { Redaksi } & \end{array}$ \\
\hline 4 & Bernas & Philippus Jehamun & $\begin{array}{ll}\text { Redaktur Halaman } \\
\text { Daerah }\end{array}$ \\
\hline 5 & TvOne (Biro Yogyakarta) & Budi Zulkifli & Kepala Biro \\
\hline 6 & $\begin{array}{l}\text { MetroTV } \\
\text { Yogyakarta) }\end{array}$ & Nizar Kherid & Kepala Biro \\
\hline 7 & $\begin{array}{c}\text { Detik.com } \\
\text { Yogyakarta) }\end{array}$ & Bagus Kurniawan & Kepala Biro \\
\hline 8 & Tempo (Biro Yogyakarta) & Pito Agustin Rudiana & Reporter \\
\hline 9 & $\begin{array}{l}\text { Republika } \\
\text { Yogyakarta) }\end{array}$ & $\begin{array}{l}\text { (1) Fernan Rahardi ; (2) Andrian } \\
\text { Saputra }\end{array}$ & $\begin{array}{l}\text { (1) Wakil kepala } \\
\text { redaksi; (2) reporter }\end{array}$ \\
\hline 10 & $\begin{array}{l}\text { Radio Republik Indonesia } \\
\text { (Yogyakarta) }\end{array}$ & Fetika Andriani & $\begin{array}{l}\text { Kepala Seksi } \\
\text { Pengembangan Berita, } \\
\text { Bidang Pemberitaan }\end{array}$ \\
\hline
\end{tabular}

*) Pada saat wawancara dilakukan

\section{HASIL DAN PEMBAHASAN}

Batasan hubungan media dalam tulisan ini adalah penyediaan informasi (information subsidies). Hal pertama dalam penyediaan informasi adalah keberadaan narasumber yang sesuai dengan kebutuhan wartawan. Dalam situasi krisis, pada umumnya wartawan menjadikan pimpinan tertinggi organisasi merupakan narasumber yang menjadi prioritas utama (Zoch dan Molleda, 2006: 284).

Narasumber dari UII adalah pimpinan universitas, humas, dan juru bicara tim pencari fakta. Berkaitan dengan kualitas narasumber resmi UII, pihak media menilai kehadiran pimpinan universitas sudah cukup untuk memberikan informasi mengenai bentuk tanggungjawab kampus. Namun begitu kehdiran pimpinan universitas sebagai narasumber dirasa masih kurang. Informan dari media televisi membutuhkan wawancara khusus dengan pimpinan universitas. Namun pihak kampus tidak menanggapi. Untuk wawancara di luar jumpa pers, UII menunjuk humas dan juru bicara tim pencari fakta sebagai narasumber.

Bagi wartawan, pimpinan tertinggi merupakan narasumber kunci dengan tingkat kredibilitas yang sangat tinggi. Kehadiran pimpinan tertinggi sudah sesuai dengan kebutuhan wartawan, sehingga membuat komunikasi yang dilakukan organisasi menjadi lebih efektif (Farihanto, 2014; Setyanto dan Anggarina, 2015). 
Terlebih, dalam situasi krisis wartawan mencari informasi dari sumbersumber resmi organisasi. Itu berarti organisasi harus proaktif dalam menempatakan juru bicara yang memang memahami konteks situasi krisis, kemudahan dalam kontak narasumber, informasi yang cepat, dan transparan (Nurjanah, dkk. 2016; Zoch dan Molleda, 2006).

Berkaitan dengan konten informasi, media menilai UII masih normative. Media masih kurang puas karena pernyataan dari tim pencari fakta dan humas masih dinilai oleh wartawan masih "takut-takut”, kurang terbuka. Bahkan ada penilaian bahwa humas dan tim pencari fakta bukanlah orang yang tepat untuk memberikan pernyataan berkaitan dengan kasus tersebut, karena tidak memahami kondisi riil di lapangan.

Hal kedua dari penyediaan informasi adalah memperhatikan informasi tentang isu serupa dari pihak lain. Salah satu pihak lain tersebut adalah pengacara (Zoch dan Molleda, 2006). Dalam situasi krisis, organisasi memang perlu memberikan perhatian terhadap keberadaan pihak lain. Pasalnya, dalam situasi krisis, organisasi harus memenangi pertarungan wacana di ranah publik. Dalam situasi krisis, "persepsi dapat diyakini sebagai kebenaran" (Kriyantono, 2012: 214). Itu sebabnya, sekalipun organisasi memiliki data yang kuat, valid, namun mereka gagal memenangi pertarungan memperebutkan persepsi publik, maka data tersebut akan tidak terlalu berguna.

Dalam kasus Diksar Mapala UII, ada pihak luar yang menamakan dirinya tim investigasi UII yang ditugasi untuk menjadi pengacara pihak Mapala UII. Pihak lain ini bahkan sampai mengadakan jumpa pers dengan menghadirkan Mapala UII, dan berlangsung di salah satu gedung UII (dalam hal menggunakan fasilitas UII). Dalam jumpa pers tersebut, tidak ada perwakilan dari UII (humas, tim pencari fakta, atau jajaran pimpinan universitas).

Beberapa saat setelah jumpa pers, muncul pernyataan dari UII bahwa jumpa pers tersebut bukan acara resmi dari UII (baca Aditya, 2017; Natalia, 2017). Kondisi ini membingungkan kebingungan di kalangan wartawan karena ada dua pihak yang mengatasnamakan UII. Organisasi mungkin bisa saja mengatakan "pihak tersebut tidak resmi", "di luar tim investigasi”, namun pihak wartawan menilai bahwa situasi ini menunjukkan ada perlunya pembenahan dalam .

Pihak lain yang juga ingin diwawancarai oleh wartawan adalah Mapala UII sebagai terduga utama (ketika itu) dalam kejadian ini. Melalui Mapala, pihak media ingin mengetahui bagaimana kejadian sebenarnya, bagaimana standar operasional prosedur (SOP) Mapala UII mulai dari pemeriksaan kesehatan calon peserta, surat izin orang tua, dan yang lainlain. Sementara, pernytaan UII secara umum baru berisi permohonan maaf dan kesiapan kampus untuk membantu menyelesaikan persoalan ini dalam hal proses hukum, kompensasi finansial bagi keluarga korban meninggal dan peserta yang menjalani pemeriksaan, serta pengunduran diri pimpinan kampus sebagai bentuk tanggungjawab.

Pernyataan itu baru menjawab kebutuhan informasi berupa tindakan yang dilakukan oleh organisasi guna mengatasi krisis. Padahal, masih ada kebutuhan informasi lain yang dibutuhkan wartawan-dan belum terjawab, yakni : (1) penjelasan mengenai kejadian/apa yang 
terjadi, (2) siapa yang terlibat dan bertanggungjawab dalam terjadinya krisis, (3) apa dampak krisis bagi masyarakat (Puspitasari, 2016). Dari wawancara, informan media secara umum ingin mengetahui tentang bagaimana kejadian sebenarnya di lapangan.

Hal ketiga dalam dalam hal teknis peliputan, organisasi harus memfasilitasi wartawan dalam proses pencarian informasi di organisasi tersebut (Zoch dan Molleda, 2006). Untuk fasilitas seperti ruang konferensi pers, akses internet selama meliput di kawasan UII, serta kemudahan dalam mengambil gambar di kawasan UII, seluruh informan menyatakan tidak ada pesoalan berarti.

Hal yang menjadi sorotan informan adalah kebijakan satu pintu yang dilakukan UII memang menyulitkan kerja wartwan. Seperti dijelaskan di atas, wartawan tidak bisa mengakses ke pihak Mapala UII. Semua informasi hanya lewat humas. Ini menimbulkan kesan UII tidak terbuka. Salah seorang informan dalam riset ini juga menyatakan ketidaknyamanan dalam meliput. Saat mewawancarai peserta Diksar Mapala UII yang tengah dirawat di rumah sakit, informan tersebut mengatakan merasa dihalang-halangi dalam liputan. Beberapa pertanyaan justru malah dijawab dari pihak humas dan tim investigasi UII yang ada di ruangan yang sama. Informan juga mengatakan bahwa pihak UII berusaha untuk membatasi pertanyaan.

Dari kajian ilmiah sebelumnya, memang ada kesan (dari wartawan) bahwa perguruan tinggi cenderung tertutup, jaga jarak, atau bahkan dalam beberapa situasi menghalangi media dalam tugasnya, ketika perguruan tinggi tersbut ditimpa isu negatif (Nurjanah, dkk. 2015; Setyanto dan Anggarina, 2015).

Masih berkaitan dengan cara organisasi memfasilitasi liputan, informan khususnya dari media online yang membutuhkan kecepatan menilai bahwa cara UII yang memberikan pernyataan resmi hanya melalui jumpa pers, kurang mendukung kebutuhan media online. Informan media online menyatakan bahwa pihaknya sudah beberapa kali mengirim WhatsApp ke pihak-pihak resmi di UII, namun mendapatkan jawaban "tunggu jumpa pers".

Meski banyak keluhan, namun sebagian besar informan mengaku dapat memaklumi kebijakan satu pintu. Ini tidak lepas karena hubungan antarlembaga yang baik yang sudah dijalin oleh UII dengan media-media tersebut. Hal ini sesuai dengan konsep yang menyatakan bahwa (humas lembaga) penting untuk mengelola relasi dengan perusahaan media massa dan individu wartawan. Hubungan yang baik memungkinkan bagi media untuk "memprioritaskan" pernyataan dari organisasi (Fil Haq, 2011; Zoch dan Molleda, 2006).

Di luar kategori dari penyediaan informasi (information subsidies), temuan dari penelitian ini adalah keputusan pengunduran diri rektor UII yang secara tidak langsung "mengurangi" tekanan media terhadap organisasi. Pengunduran diri tersebut sebenarnya sudah disampaikan di Kopertis Wilayah V Yogyakarta pada hari Kamis 26 Januari 2017, ketika itu juga hadir Menristek Dikti. Namun moment penting terjadi pada hari Minggu 29 Januari 2017 di mana Rektor UII memberikan pernyataan di hadapan civitas akademika UII, menjelaskan alasan dari pengunduran diri tersebut. Sejak itu 
sorotan media terhadap UII menjadi berkurang. Bahkan salah seorang informan penelitian ini mengaku secara pribadi memperoleh kesan mendalam tentang sosok rektor UII, sehingga ia merasa bahwa tidak perlu lantas memojokkan UII dalam pemberitaan, terlepas dari adanya kekurangan dalam menyediakan informasi.

Sejarah krisis, yakni pengalaman organisasi dalam menghadapi krisis menjadi salah satu hal yang mempengaruhi persepsi publik terhadap krisis dan organisasi tersebut (Kriyantono, 2012: 250). Dalam kasus UII, penulis berpendapat bahwa persepsi wartawan terhadap UII juga dipengaruhi tentang peristiwa-peristiwa di waktu lalu yang terjadi di lembaga pendidikan lain saat menangani krisis berkaitan dengan kejadian meninggal tidak wajar yang dialami peserta didik. Ada kemungkinan, keputusan rektor UII -dan wakil rektor bidang kemahasiswaan-- mengundurkan diri secara sukarela belum pernah terjadi di tempat lain.

Dukungan juga hadir dari orangtua mahasiswa UII yang menjadi peserta Diksar Mapala 2017, yang menyatakna kurang setuju jika rektor UII sampai harus mengundurkan diri akibat peristiwa ini (Kusuma, 2017)

\section{DISKUSI DAN PEMBAHASAN}

Di bagian diskusi penulis akan memaparkan pentingnya memiliki sense of crisis bagi humas dan pimpinan perguruan tinggi. Humas memegang peranan penting dalam manajemen krisis (Ngurah Putra, 1999) sementara pimpinan organisasi berpengaruh pada jalannya komunikasi krisis (Ulmer, et.al., 2011) dan kinerja humas secara keseluruhan (Sati, 2017; Setyanto dan Anggarina 2015). Diskusi akan terdiri dari dua bagian: pertama tentang kaitan antara kinerja humas dengan pimpinan perguruan tinggi, kedua adalah keterlibatan pimpinan dalam manajemen krisis.

Humas perguruan tinggi perlu memiliki panduan dalam menghadapi situasi krisis, dalam konteks tulisan ini adalah bagaimana menghadapi media dalam situasi krisis. Selama ini, aktivitas hubungan media perguruan tinggi didominiasi oleh tujuan untuk membentuk citra positif di organisasi melalui pencapaian-pencapaian perguruan tinggi (Farihanto, 2014; Nurjanah, dkk. 2015; Nurjanah, dkk. 2016; Sati, 2017; Setyanto dan Anggarina, 2015). Padahal, di sisi lain hubungan media juga memengang peranan penting dalam situasi krisis. Sebelum masuk ke sana, humas perguruan tinggi harus memahami bahwa perguruan tinggi tidak kebal terhadap krisis. Meski bisnis perguruan tinggi lebih minim risiko (dibandingkan dengan perusahaan profit seperti pertambangan, maskapai penerbangan), namun tetap saja potensi krisis itu ada dan dapat menjadi semakin parah apabila tidak diatasi. Perlu diingat bahwa organisasi, apa pun bentuknya, dapat terkena krisis (Barton, dalam Ngurah Putra 1999).

Panduan ini penting karena berdasarkan literatur yang ada, kebanyakan perguruan tinggi di Indonesia belum memiliki panduan dalam menghadapi isu negatif (Ariani, 2016). Panduan tersebut penting, bagi seluruh kegiatan kehumasan, tujuannya agar kegiatan kehumasan tersebut dapat berjalan secara terarah dan terukur (Sati, 2017). 
Dari hasil penelitian, informan yang merupakan wartawan media local di Yogyakarta mengungkap beberapa kekurangan dari UII yakni dalam hal kebutuhan informasi, keterbukaan informasi, dan koordinasi internal. Itu sebabnya, perguruan tinggi perlu memiliki manual crisis plan. Panduan tersebut penting untuk menentukan siapa saja yang menjadi juru bicara, bagaimana koordinasi antar unitkerja dalam perguruan tinggi, apa saja yang bisa dilakukan untuk memfasilitasi wartawan dalam liputan (yang mana hal ini bisa dipetakan dengan melihat pada platform atau jenis medianya, struktur kepemilikan media tersebut, hubungan antara organisasi dengan media tersebut di situasi sebelumnya), dan lainlain.

Aktivitas hubungan media pun juga sebaiknya jangan berhenti ketika intensitas liputan media menurun. Pasca-krisis, perguruan tinggi juga perlu melanjutkan dengan menjalin hubungan yang lebih baik dengan media baik itu secara lembaga mau pun secara personal, antara humas dengan individu wartawan (Fil-Haq, 2011; Miela Putra, 2012).

Dari temuan penelitian, masih ada beberapa media yang mengeluhkan layanan informasi dari UII. Hal ini perlu ditindaklanjuti. Belajar dari organisasi lain, misalnya Lion Air, Untuk media yang memberitakan negatif, maskapai penerbangan tersebut melakukan kunjungan langsung ke media untuk bertemu dengan pimpinan media bersangkutan, tujuannya adalah bersilaturahmi agar terjadi kesepahaman antara kedua belah pihak. Ada pun dengan yang memberitakan secara positif, kegiatan media relations terus dilakukan agar media tersebut menjadi lebih aware kepada perusahaan jika ada pemberitaan berikutnya maka media tersebut diharapkan antusias untuk memberitakan perusahaan terkait dengan citra (Miela Putra, 2012).

Berkaitan dengan hal pertama yakni keterkaitan antara kinerja humas dengan pimpinan tertinggi, maka kesadaran dan pemahaman dari humas tentu akan sia-sia jika tidak ada dukungan dari jajaran top management. Sejumlah literatur menyinggung tentang kurangnya pemahaman pimpinan tentang humas, menyebabkan kinerja humas di perguruan tinggi menjadi tidak maksimal. Kurangnya pemahaman terlihat pada penempatan unit kerja humas di posisi yang kurang penting dalam struktur organisasi, hingga terbatasnya anggaran untuk melakukan aktivitas kehumasan. Padahal idealnya posisi humas berada dalam struktur yang dekat dengan top management, agar dapat terlibat dalam pengambilan keputusan (Sati, 2017: 129 ; Setyanto dan Anggarina, 2015: 221).

Hal kedua adalah keterlibatan pimpinan dalam manajemen krisis. Pimpinan UII (rektor dan pembantu rektor) menjadi narasumber dalam setiap pernyataan resmi yang disampaikan lewat jumpa pers. Informan dalam penelitian ini secara umum menyatakan kehadiran dalam jumpa pers masih belum cukup, karena masih ada informasi yang ingin digali. Tetapi pada prinsipnya mereka memaklumi pembatasan yang dilakukan oleh UII.

Dalam literatur memang disebutkan keputusan organisasi untuk membatasi akses liputan bisa berisiko besar bagi organisasi, karena akan menimbulkan kesan bahwa organisasi menyembunyikan sesuatu (Ulmer, et.al 2011). Selain itu media juga akan mencari narasumber lain, 
di luar organisasi (Zoch dan Molleda, 2006). Tidak ada jaminan bahwa pernyataan dari narasumber lain tersebut tidak merugikan organisasi.

Namun terlalu sering tampil di media juga berpotensi menimbulkan kesan negatif di mata publik. Bisa timbul kesan bahwa pimpinan organisasi terlalu sibuk melakukan pencitraan dan tidak menyelesaikan masalah. Lalu harus bagaimana? Ulmer, et.al (2011) menawarkan konsep menarik mengenai "kepemimpinan yang menuntujukkan kebajikan/kebaikan hati" (leadership virtues). Dalam situasi krisis, pemimpin perlu menunjukkan tindakan yang sesuai dengan tuntutan etika. Seseorang yang memiliki kebajikan merupakan orang yang berusaha untuk melakukan tindakan secara jujur, tulus, dan bertanggungjawab (Ulmer, et.al., 2011: 72-73).

Keputusan Rektor UII untuk mengundurkan diri secara sukarela, selanjutnya memberikan pernyataan resmi kepada civitas akademika UII menjadi salah satu titik penting dalam perjalanan krisis Mapala UII ini. Sejak itu, sorotan media terhadap UII menjadi berkurang. Ini merupakan praktek dari leadership virtues yang menunjukkan bahwa pimpinan UII bertindak sesuai dengan halhal yang etis yakni mengundurkan diri ketika ada masalah. Sebuah hal yang mungkin jarang terjadi ketika sebuah perguruan tinggi dilanda masalah besar. Menurut Ulmer, et.al (2011: 75) respon (pimpinan) organisasi dalam bentuk menunjukkan kebajikan yang sesuai dengan nilai-nilai etika yang diharapkan publik, dapat membantu organisasi memperoleh dukungan.

\section{KESIMPULAN}

Perguruan tinggi merupakan organisasi yang juga rentan terhadap krisis. Di Indonesia, sejumlah kejadian baik itu yang bersifat akademik mau pun non-akademik dapat memicu krisis bagi perguruan tinggi. Plagiasi, adanya aturan baru, konflik internal organisasi, hingga kematian tak wajar peserta didik dalam lingkup kegiatan kampus adalah contohnya. Krisis dapat semakin memburuk manakala organisasi tersebut tidak siap. Perguruan tinggi mungkin kurang familiar dengan krisis, sehingga mereka tidak memiliki sense of crisis.

Penulis berharap tulisan ini memberikan pemahaman tentang pentingnya memiliki dan memahami sense of crisis bagi humas dan pimpinan perguruan tinggi. Bagi humas adalah tentang bagaimana harus melakukan koordinasi internal, mengatur siapa juru bicara yang akan memberikan keterangan, pemahaman tentang karakteristik media berdasarkan platform, dan sebagainya.

Bagi pimpinan juga diperlukan pemahaman guna memaksimalkan peran dan fungsi humas di perguruan tinggi. Selain itu, hal yang mungkin juga layak menjadi perhatian adalah bagaimana pimpinan di UII menunjukkan "kepemimpinan yang menunjukkan kebajikan” dalam komunikasi krisis. Tentu saja, hal ini harus didasari oleh niatan yang tulus dan ikhlas, dan bukan hanya sekadar membentuk citra positif.

Penulis mengucapkan terima kasih, pertama kepada narasumber dari perwakilan media yang telah memberikan izin untuk diwawancarai. Informasi tersebut sangat berguna sebagai masukan kepada lembaga perguruan tinggi, sekaligus bagi pengembangan ilmu 
pengetahuan khususnya di bidang kehumasan dan manajemen krisis. Kedua, kepada Program Studi Ilmu Komunikasi, Fakultas Psikologi dan Ilmu Sosial Budaya, Universitas Islam Indonesia, atas dukungannya terhadap penelitian ini.

Penulis berharap naskah ini dapat menambah khazanah kajian dalam manajemen krisis di organisasi perguruan tinggi. Pasalnya, belum banyak pembahasan mengenai manajemen krisis perguruan tinggi. Kajian manajemen krisis masih didominasi dengan contoh kasus di perusahaan (Gainey, 2010: 301). Dalam konteks Indonesia, pemaparan tentang krisis memang ditemukan dalam beberapa sumber, namun krisis hanya menjadi bagian/sub-bab dari pembahasan secara umum mengenai humas di perguruan tinggi atau hubungan media yang dilakukan humas perguruan tinggi (baca: Fatonah dan Utami, 2015; Nurjanah, dkk. 2015; Sati, 2017; Setyanto dan Anggarina, 2015)

Tulisan ini masih memiliki keterbatasan karena baru membahas dari segi aktivitas hubungan media yang dilakukan oleh perguruan tinggi ketika krisis. Untuk penelitian selanjutnya dapat membahas hubungan antara perguruan tinggi dengan pemangku kepentingan lain. Keterbatasan lain adalah dari segi kasus, karena krisis sendiri merupakan kasus yang spesifik. Penelitian lain dapat membahas tentang krisis yang menimpa perguruan tinggi dari kasus yang lain misalkan yang menyangkut pelanggaran terhadap akademik. 


\section{DAFTAR PUSTAKA}

Ariani, R. (2016). "Peran Public Relations Dalam Manajemen Isu di UGM (Studi Kasus Peran Humas UGM dalam Mengelola Isu Relokasi Kantin Humaniora Mandiri UGM)". Master Thesis. Yogyakarta: Universitas Gadjah Mada

Farihanto, M.N. (2014) “Teman tapi Mesra Humas dan Wartawan (Studi Kasus Strategi Hubungan Media di Bidang Humas dan Protokoler Universitas Ahmad Dahlan)" Jurnal Komunikasi PROFETIK, 7 (2), Oktober : 53-64

Fatonah, S dan Utami, Y.S. (2015) "Peran dan Strategi Humas Perguruan Tinggi (Studi Deskripsi Humas UPN "Veteran" Yogyakarta dan Universitas Gadjah Mada" Aswad Ihsak (Editor), Komunikasi dan Isu Publik. Yogyakarta: ASPIKOM, Unika Widya Mandala Surabaya, Univ. Kristen Petra Surabaya, Univ. Muhammadiyah Malang, dan Penerbit Buku Litera.

Fil-Haq, A. (2011) "Penanganan Krisis Public Relations Melalui Media Relations PT PLN (Persero) APJ Banten Utara. URL : http://download.portalgaruda.org/a rticle.php?article $=49051 \& \mathrm{val}=4028$, diakses 1 Mei 2017

Gainey, B.S. (2010) "Educational Crisis Management Practices Tentatively Embrace the New Media". W.Timothy Coombs and Sherry J.Holladay (Editors) The Handbook of Crisis Communication. West Sussex, UK: Wiley-Blackwell

Hariyanti, P (2009) "Mencari Solusi Kritis di Tengah Krisis" . Jurnal Komunikasi 3 (2) : 189-197. URL : http://journal.uii.ac.id/jurnalkomunikasi/article/view/6815/6035 , diakses 1 Mei 2017
Kriyantono, R. (2012) Public Relations \& Crisis Management. Jakarta: Kencana Prenada Media Grup.

Miela Putra, O.W. (2012) "Manajemen Krisis PT Lion Mentari Airlines dalam Menangani Berita-Berita Negatif di Media”. Skripsi. Jakarta: Universitas Indonesia

Ngurah Putra, I.G (1999) Manajemen Hubungan Masyarakat. Yogyakarta: Univ.Atma Jaya

Nurjanah, A., Widyasari, W., dan Yulianti, F. (2015) "Wartawan dan Budaya Amplop: Budaya Amplop pada Wartawan Pendidikan dalam Kaitannya dengan Media Relations" Jurnal Informasi, 45 (1): 15-24. URL:

https://journal.uny.ac.id/index.php informasi/article/view/7766/6683, diakses 1 Mei 2017

Nurjanah, A., Widyasari, W., dan Yulianti, F. (2016) Public Relations dan Media Relations: Kajian Kritis Budaya Amplop pada Media Relations Institusi Pendidikan Tinggi di Yogyakarta. URL : http://repository.umy.ac.id/bitstrea $\mathrm{m} /$ handle/123456789/1388/PNLT2 226.pdf? sequence $=2 \&$ isAllowed $=\mathrm{y}$, diakses 18 November 2017

Puspitasari (2016) Komunikasi Krisis: Straegi Mengeola dan Memenangkan Citra di Mata Publik. Jakarta: Penerbit Libri

Sa'diyah, H. (2017) "Manajemen Krisis Universitas Islam Indonesia (UII) Yogyakarta dalam Mengatasi Kasus Mapala Unisi” Jurnal Ilmu Komunikasi AKRAB, 2 (1) : 134-147. URL:

http://ojs.akrb.ac.id/index.php/akr ab/article/view/39/18, diakses 1 Mei 2018 
Sati, I (2017) "Pengalaman Mengelola Public Relations di Lembaga Pendidikan Tinggi. Setio Budi H. Hutomo (Editor). Public Relations Kompetensi dan Kearifan Lokal. Yogyakarta: Perhumas, ASPIKOM, Buku Litera

Setyanto, Y. \& Anggarina, P. T. (2015). "Humas pada Perguruan Tinggi Hubungan dengan Media pada Institusi Pendidikan". Aswad Ihsak (Editor), Komunikasi dan Isu Publik. Yogyakarta: ASPIKOM, Unika Widya Mandala Surabaya, Univ. Kristen Petra Surabaya, Univ. Muhammadiyah Malang, dan Penerbit Buku Litera.

Ulmer, R.R., Sellnow, T.L., Seeger, M.W (2011) Effective Crisis Communication Moving From Crisis to Opportunity $2^{\text {nd }}$ Edition. Thousand Oaks, California : SAGE

Zoch, L.M. dan Molleda, J.C. (2006) "Building a Theoretical Model of Media Relations using Framing, Information Subsidies, and AgendaBuilding” Carl H. Botan \& Vincent Hazelton (Editors) Public Relations Theory II. Mahwah, New Jersey: Lawrence Erlbaum Associates

\section{SUMBER DARI BERITA MEDIA}

Aditya, I (2017) "Pernyataan Mapala UII Tak Pengaruhi Investigasi". Media : www.krjogja.com, tanggal publikasi : 28 Januari 2017. URL : http://krjogja.com/web/news/read/ 22860/Pernyataan Mapala UII Ta k Pengaruhi Investigasi , tanggal akses : 19 Desember 2017

Kusuma, W (2017) "Orangtua korban Kurang Setuju Rektor UII Mundur". Media : www.kompas.com, tanggal publikasi 28 Januari 2017. URL : http://regional.kompas.com/read/2 017/01/28/07105111/orangtua.korb an.kurang.setuju.harsoyo.mundur.se bagai.rektor.uii , tanggal akses : 19 Desember 2017

Natalia, MD (2017) "Achiel Suyanto Bukan Anggota Tim Investigasi”. Media: www.harianjogja.com, tanggal publikasi 27 Januari 2017. URL : http://www.harianjogja.com/baca/2 017/01/27/mahasiswa-uiimeninggal-achiel-suyanto-bukananggota-tim-investigasi-788277, tanggal akses: 19 Desember 2017. 